Jurnal Ilmiah Matematika dan Pendidikan Matematika (JMP)

Vol. 10 No. 1, Juni 2018, hal. 1-16

ISSN (Cetak) : 2085-1456; ISSN (Online) : 2550-0422

\title{
ALGORITMA FUZZY GOAL PROGRAMMING UNTUK MASALAH PEMROGRAMAN BILEVEL MULTIOBJEKTIF
}

\author{
Syarifah Inayati \\ Program Studi Statistika, Fakultas MIPA \\ Universitas Negeri Yogyakarta \\ syarifah.inayati@uny.ac.id
}

\begin{abstract}
Bilevel multiobjective programming problems are mathematical programming that solves the problem of planning with two decision makers (DM) in two level or hierarchical organization with the objective function of each organization can be more than one. In this paper, we discussed the special case of this problem with single decision maker at the upper level and multiple decision makers at the lower level. This problem can be solved using fuzzy goal programming (FGP) approach. In this approach, the membership function for the defined fuzzy goals of all objective functions of DMs at the two levels was developed first in the model formulation of the problem. Thus the membership function for vector of fuzzy goals of the decision variables controlled by the leader. Then FGP approach requires the leader to set goals for each objective that he/she wishes to attain. A preferred solution is then defined for minimizes the deviations from the set of goals. Numerical example is provided to illustrate the approach.
\end{abstract}

Keywords: multiobjective programming, bilevel programming, fuzzy goal programming.

\begin{abstract}
ABSTRAK. Masalah pemrograman bilevel multiobjektif, yaitu pemrograman matematika yang memecahkan masalah perencanaan desentralisasi dengan dua pengambil keputusan atau Decision Making (DM) dalam dua level atau organisasi hirarki dengan fungsi tujuan dari masing-masing organisasi dapat lebih dari satu. Dalam makalah ini, kami membahas suatu permasalahan yang melibatkan satu pengambil keputusan (tunggal) pada masalah tingkat atas dan dua atau lebih pengambil keputusan (ganda) pada masalah tingkat bawah. Masalah ini dapat diselesaikan dengan menggunakan pendekatan fuzzy goal programming (FGP). Dalam pendekatan ini, fungsi keanggotaan untuk mendefinisikan fuzzy goal terhadap fungsi objektif para DM pada kedua tingkat dikembangkan pertama dalam model perumusan masalah. Sedemikian sehingga fungsi keanggotaan untuk vektor fuzzy goal terhadap variable-variabel keputusan dikendalikan oleh leader. Kemudian leader menetapkan tujuan untuk setiap tujuan yang ingin dicapai. Solusi yang memuaskan kemudian didefinisikan untuk meminimumkan penyimpanganpenyimpangan dari tujuan-tujuan tertentu. Ilustrasi contoh numerik diberikan untuk memperlihatkan prosedur dari algoritma ini dalam penyelesaian masalah.
\end{abstract}

Kata Kunci: pemrograman multiobjektif, pemrograman bilevel, fuzzy goal programming.

\section{Pendahuluan}

Masalah pemrograman bilevel merupakan masalah pemrograman multilevel dengan dua tingkat. Dalam permasalahan ini melibatkan dua pengambil keputusan/ Decision Maker (DM) yaitu pengambil keputusan tingkat pertama 
(leader) dan pengambil keputusan tingkat kedua (follower). Dasar hubungan dalam teknik pemrograman bilevel adalah bahwa leader menetapkan goal dan/atau keputusan, kemudian meminta follower menghitung solusi optimal secara terpisah, dan kemudian hasil keputusan dari follower kemudian diserahkan dan dimodifikasi oleh leader dengan pertimbangan keseluruhan keuntungan bagi organisasi. Proses dapat berlanjut hingga solusi yang optimal tercapai.

Pada sebagian besar masalah pemrograman bilevel, setiap pengambil keputusan mempunyai tujuan yang tunggal dengan dihadapkan masing-masing kendala yang dimiliki. Padahal, dalam kehidupan sehari-hari sering ditemui suatu permasalahan pemrograman bilevel yang mempunyai tujuan lebih dari satu dan tujuan-tujuan tersebut perlu diselesaikan secara simultan. Sehingga diperlukan suatu konsep penyelesaian permasalahan multiobjektif. Lebih lanjut, permasalahan ini dapat dikembangkan sebagai masalah pemrograman bilevel multiobjektif yaitu masalah pemrograman bilevel dengan fungsi tujuan dari masing-masing organisasi dapat lebih dari satu. Selanjutnya, permasalahan ini akan diselesaikan dengan menggunakan pendekatan Fuzzy Goal Programming (FGP).

\section{Formulasi Masalah Pemrograman Bilevel Multiobjektif}

Dalam penelitian ini dibatasi untuk permasalahan pemrograman bilevel multiobjektif linier (Bi-level Multi-objective Linear Programming/ BL-MOLP) yaitu permasalahan multiobjektif yang melibatkan satu pengambil keputusan (tunggal) pada masalah tingkat atas (ULDM/ Upper Level Decision Maker) dan dua atau lebih pengambil keputusan (ganda) pada masalah tingkat bawah (LLDM/ Lower Level Decision Maker). Sedangkan untuk fungsi objektif dari masingmasing pengambil keputusan/ Decision Making (DM) beserta kendala-kendala yang dimiliki adalah fungsi linear.

Pada permasalahan ini diasumsikan bahwa terdapat dua tingkat dalam struktur hierarki masalah dengan satu ULDM atau $\mathrm{DM}_{0}$ dan sebanyak $p$ DM pada $\operatorname{LLDM}_{k}$ atau $\mathrm{DM}_{k}$, dengan $k=1,2, \ldots, p$. Misalkan vektor-vektor variabel keputusan $\boldsymbol{x}=\left(\boldsymbol{x}_{0}, \boldsymbol{x}_{1}, \ldots, \boldsymbol{x}_{p}\right) \in \mathbb{R}^{n}$ dipartisi antara ULDM dan $\mathrm{LLDM}_{k}$, maka 
ULDM memiliki kontrol atas vektor $\boldsymbol{x}_{0} \in \mathbb{R}^{n_{0}}$ dan $\operatorname{LLDM}_{k}$ dengan $k=1,2, \ldots, p$ memiliki kontrol atas vektor $\boldsymbol{x}_{k} \in \mathbb{R}^{n_{k}}$, dengan $n=n_{0}+n_{1}+\cdots+n_{p}$ dan $\boldsymbol{x}_{k}=\left(x_{k 1}, x_{k 2}, \ldots, x_{k n_{k}}\right), \quad k=0,1,2, \ldots, p$. Selanjutnya diasumsikan bahwa $F_{i}\left(x_{0}, x_{1}, \ldots, x_{p}\right)$ sebagai

$$
F_{i}(\boldsymbol{x}): \mathbb{R}^{n_{0}} \times \mathbb{R}^{n_{1}} \times \ldots \times \mathbb{R}^{n_{p}} \rightarrow \mathbb{R}^{m_{i}}, i=0,1, \ldots, p
$$

adalah vektor dari fungsi objektif $\mathrm{DM}_{i}, i=0,1, \ldots, p$. Lebih lanjut dalam Baky (2009) permasalahan pemrograman bilevel multiobjektif dapat dirumuskan sebagai berikut:

\section{(upper level)}

$\left[D M_{0}\right]: \min _{x_{0}} F_{0}(\boldsymbol{x})=\min _{x_{0}}\left(f_{01}(\boldsymbol{x}), f_{02}(\boldsymbol{x}), \ldots, f_{0 m_{0}}(\boldsymbol{x})\right)$

dengan $x_{1}, x_{2}, \ldots, x_{p}$ menyelesaikan

\section{(lower level)}

$$
\begin{aligned}
& {\left[D M_{1}\right]: \min _{x_{1}} F_{1}(\boldsymbol{x})=\min _{x_{1}}\left(f_{11}(\boldsymbol{x}), f_{12}(\boldsymbol{x}), \ldots, f_{1 m_{1}}(\boldsymbol{x})\right)} \\
& {\left[D M_{2}\right]: \min _{x_{2}} F_{2}(\boldsymbol{x})=\min _{x_{2}}\left(f_{21}(\boldsymbol{x}), f_{22}(\boldsymbol{x}), \ldots, f_{2 m_{2}}(\boldsymbol{x})\right)} \\
& \vdots \\
& {\left[D M_{p}\right]: \min _{x_{p}} F_{p}(\boldsymbol{x})=\min _{x_{p}}\left(f_{p 1}(\boldsymbol{x}), f_{p 2}(\boldsymbol{x}), \ldots, f_{p m_{p}}(\boldsymbol{x})\right)}
\end{aligned}
$$

dengan kendala

$$
\boldsymbol{x} \in G=\left\{x \in \mathbb{R}^{n} \mid A_{0} x_{0}+A_{1} x_{1}+\cdots+A_{p} x_{p}\left(\begin{array}{l}
\leq \\
= \\
\geq
\end{array}\right) \boldsymbol{b}, \boldsymbol{x} \geq 0, \boldsymbol{b} \in \mathbb{R}^{n}\right\} \neq \emptyset
$$

dengan

$$
\begin{aligned}
f_{i j}(\boldsymbol{x})= & c_{0}^{i j} \boldsymbol{x}_{0}+c_{1}^{i j} \boldsymbol{x}_{1}+\cdots+c_{p}^{i j} \boldsymbol{x}_{p}, i=0,1, \ldots, p, j=1,2, \ldots, m_{i} \\
= & c_{01}^{i j} x_{01}+c_{02}^{i j} x_{02}+\cdots+c_{0 n_{0}}^{i j} x_{0 n_{0}}+c_{11}^{i j} x_{11}+c_{12}^{i j} x_{12}+\cdots+c_{1 n_{1}}^{i j} x_{1 n_{1}} \\
& +c_{21}^{i j} x_{21}+c_{22}^{i j} x_{22}+\cdots+c_{2 n_{2}}^{i j} x_{2 n_{2}}+\cdots+c_{p 1}^{i j} x_{p 1}+c_{p 2}^{i j} x_{p 2}+\cdots+ \\
& c_{0 n_{0}}^{i j} x_{0 n_{0}}
\end{aligned}
$$

dan $m_{i}, i=0,1,2, \ldots, p$ adalah jumlah fungsi-fungsi objektif $\mathrm{DM}_{i}, m$ adalah banyaknya kendala, $c_{k}^{i j}=\left(c_{k 1}^{i j}, c_{k 2}^{i j}, \ldots, c_{k n_{k}}^{i j}\right), k=0,1,2, \ldots, p$ dan $c_{k n_{k}}^{i j}$ adalah konstan, $A_{i}$ adalah matriks koefisien berukuran $m \times n_{i}$. 


\section{Formulasi Model Fuzzy Goal Programming (FGP)}

Untuk merumuskan model FGP dari masalah pemrograman bilevel multiobjektif, fuzzy goal dari tujuan dicari dengan menentukan solusi optimal individu. Dalam permasalahan ini, fuzzy goal dalam FGP dianggap sebagai tujuan dengan level aspirasi tidak tepat yang ditugaskan untuk masing-masing tujuan $\left(f_{i j}(\boldsymbol{x}), i=0,1, \ldots, p, j=1,2, \ldots, m_{i}\right)$. Fuzzy goal kemudian ditandai dengan fungsi keanggotaan asosiasi dengan mendefinisikan batas toleransi untuk pencapaian level aspirasi dari masing-masing fuzzy goal.

\subsection{Konstruksi fungsi keanggotaan}

Karena semua DM memiliki tujuan untuk meminimalkan fungsi objektif mereka sendiri dalam daerah feasibel yang telah didefinisikan oleh sistem kendala (2), solusi optimal dari masing-masing DM dapat dihitung secara terpisah kemudian dapat diambil sebagai level aspirasi dari fuzzy goal asosiasi.

Misalkan, $\quad \boldsymbol{x}^{i j}=\left(\boldsymbol{x}_{0}^{i j}, \boldsymbol{x}_{1}^{i j}, \ldots, \boldsymbol{x}_{p}^{i j}\right) ; \quad f_{i j}^{\min }, i=0,1,2, \ldots, p, j=1,2, \ldots, m_{i}$ adalah solusi optimal dari fungsi objektif para DM di kedua tingkat yang ditentukan secara terpisah. $g_{i j} \geq f_{i j}^{\text {min }}$ adalah level aspirasi yang ditugaskan untuk masing-masing fungsi objektif $f_{i j}(\boldsymbol{x})$ (indeks -ij berarti bahwa $j=1,2, \ldots, m_{0}$ ketika $i=0$ untuk masalah $\mathrm{DM}_{0}, j=1,2, \ldots, m_{1}$ ketika $i=1$ untuk masalah $\mathrm{DM}_{1}$, dan $j=1,2, \ldots, m_{p}$ ketika $i=p$ untuk masalah $\mathrm{DM}_{p}$ ). Dan diberikan $\boldsymbol{x}^{\mathbf{0}^{*}}=\left(\boldsymbol{x}_{0}^{*}, \boldsymbol{x}_{1}^{*}, \ldots, \boldsymbol{x}_{p}^{*}\right)$ sebagai solusi optimal masalah tingkat atas dari masalah MOLP. Kemudian, fuzzy goal dari fungsi objektif para DM pada kedua tingkat dan vektor fuzzy goal dari variabel keputusan yang dikontrol oleh $\mathrm{DM}_{0}$ dan $\mathrm{DM}_{k}$, dengan $k=1,2, \ldots, p$ muncul sebagai

$$
f_{i j}(\boldsymbol{x}) \preccurlyeq g_{i j}, i=0,1, \ldots, p, j=1,2, \ldots, m_{i} \text { dan } \boldsymbol{x}_{0} \cong x_{0}^{*}
$$

dengan " $\preccurlyeq "$ dan " $\cong$ " menunjukkan level aspirasi yang bersifat fuzzy, artinya $" \preccurlyeq "$ dan " $\cong "$ menunjukkan versi fuzzy dari $\leq$ dan $=$.

Dapat diperhatikan bahwa solusi $x^{i j}=\left(x_{0}^{i j}, x_{1}^{i j}, \ldots, x_{p}^{i j}\right)$; $i=0,1,2, \ldots, p, j=1,2, \ldots, m_{i}$ biasanya berbeda karena pada dasarnya tujuan 
antara ULDM dan LLDM adalah saling bertentangan. Oleh karena itu, dapat diasumsikan bahwa nilai $f_{l m}\left(\boldsymbol{x}_{1}^{l m}, \boldsymbol{x}_{2}^{l m}, \ldots, \boldsymbol{x}_{p}^{l m}\right) \geq f_{i j}^{\min }, \forall l=0,1, \ldots, p, j=$ $1,2, \ldots, m_{i}$, dan $i j \neq l m$ dan semua nilai yang lebih besar $f_{l m}^{u}=\max \left[f_{i j}\left(\boldsymbol{x}_{1}^{l m}, \boldsymbol{x}_{2}^{l m}, \ldots, \boldsymbol{x}_{p}^{l m}\right), i=0,1,2, \ldots, p, j=1,2, \ldots, m_{i} \quad\right.$ dan $\left.\quad i j \neq l m\right]$ sebenarnya tidak dapat diterima untuk fungsi objektif $f_{l m}(\boldsymbol{x}) \equiv$ $f_{l m}\left(\boldsymbol{x}_{1}, \boldsymbol{x}_{2}, \ldots, \boldsymbol{x}_{p}\right)$. Dengan demikian, $f_{l m}(\boldsymbol{x})$ dapat dianggap sebagai batas toleransi atas $u_{l m}$ dari fuzzy goal untuk fungsi-fungsi objektif. Sedemikian sehingga, fungsi keanggotaan $\mu_{f i j}\left(f_{i j}(\boldsymbol{x})\right)$ untuk fuzzy goal ke-ij dapat dirumuskan sebagai berikut.

$$
\mu_{f_{i j}}\left(f_{i j}(\boldsymbol{x})\right)=\left\{\begin{array}{c}
1, \quad \text { jika } f_{i j}(\boldsymbol{x}) \leq g_{i j} \\
\frac{u_{i j}-f_{i j}(\boldsymbol{x})}{u_{i j}-g_{i j}}, \text { jika } g_{i j} \leq f_{i j}(\boldsymbol{x}) \leq u_{i j}, i=0,1, \ldots, p, j= \\
0, \quad \text { jika } f_{i j}(\boldsymbol{x}) \geq u_{i j}
\end{array}\right.
$$

Berikut diberikan gambar fungsi keanggotaan (4).

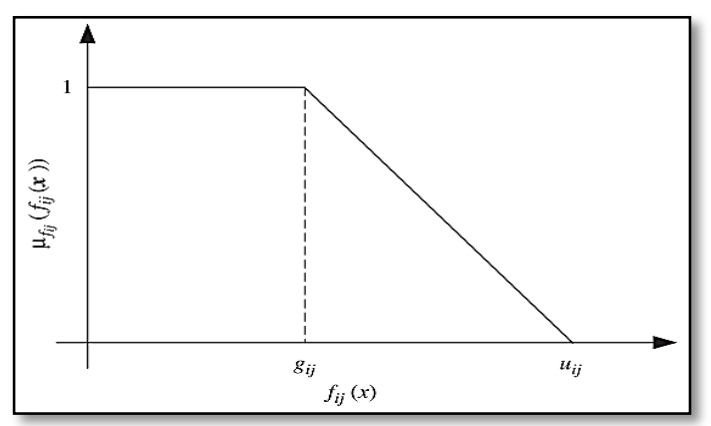

Gambar 3.1. Fungsi keanggotaan dari fungsi objektif minimisasi

Untuk membangun fungsi keanggotaan untuk fuzzy goal dari variabel keputusan yang dikontrol oleh ULDM, solusi optimal dari masalah tingkat atas MOLP, $\boldsymbol{x}^{0^{*}}=\left(\boldsymbol{x}_{0}^{*}, \boldsymbol{x}_{1}^{*}, \ldots, \boldsymbol{x}_{p}^{*}\right), \boldsymbol{x}_{0}^{*}=\left(x_{01}^{*}, x_{02}^{*}, \ldots, x_{0 n_{0}}^{*}\right)$, harus ditentukan terlebih dahulu. Solusi optimal $\boldsymbol{x}^{0^{*}}$ dapat diperoleh dengan menggunakan pendekatan FGP dari Mohamed (1997) yang menyelesaikan masalah single-level MOLP, dalam 
makalah ini, untuk menyelesaikan masalah tingkat atas MOLP. Formulasi model FGP dari pendekatan ini dapat dinyatakan sebagai berikut.

$\min Z=\sum_{j=1}^{m_{0}} w_{0 j}^{+} d_{0 j}^{+}$

dengan kendala

$$
\begin{aligned}
& \frac{u_{0 j}-\left(c_{1}^{0 j} x_{1}+c_{2}^{0 j} x_{2}+\cdots+c_{p}^{0 j} x_{p}\right)}{u_{0 j}-\mathrm{g}_{0 j}}+d_{0 j}^{-}-d_{0 j}^{+}=1, j=1,2, \ldots, m_{0} \\
& A_{1} x_{1}+A_{2} x_{2}+\cdots+A_{p} x_{p}\left(\begin{array}{c}
\leq \\
= \\
\geq
\end{array}\right) \boldsymbol{b}, \boldsymbol{x} \geq 0 \\
& d_{0 j}^{-} \times d_{0 j}^{+}=0 \text { dan } d_{0 j}^{-}, d_{0 j}^{+} \geq 0, j=1,2, \ldots, m_{0}
\end{aligned}
$$

dengan $d_{0 j}^{-}, d_{0 j}^{+}, j=1,2, \ldots, m_{0}$ menyatakan deviasi atas dan bawah dari level aspirasi. Dan bobot $w_{0 j}^{+}, j=1,2, \ldots, m_{0}$ menyatakan kepentingan relatif mencapai level aspirasi dari fuzzy goal terhadap batasan yang ditetapkan dalam situasi keputusan. Untuk menilai kepentingan relatif dari fuzzy goal dengan benar, skema pembobotan yang disarankan oleh Mohamed (1997) dapat digunakan untuk menetapkan nilai-nilai $w_{0 j}^{+}, j=1,2, \ldots, m_{0}$. Dalam formulasi ini, nilai-nilai ini ditentukan sebagai berikut.

$$
w_{0 j}^{+}=\frac{1}{u_{0 j}-g_{0 j}}, j=1,2, \ldots, m_{0}
$$

Selanjutnya, ULDM memberikan suatu toleransi kepada vektor keputusan $\boldsymbol{x}^{0^{*}}=\left(x_{01}^{*}, x_{02}^{*}, \ldots, x_{0 n_{0}}^{*}\right)$ sedemikian sehingga LLDM dapat mencari solusi optimalnya di dalam daerah feasibel yang lebih luas, perhatikan Gambar 3.2 berikut.

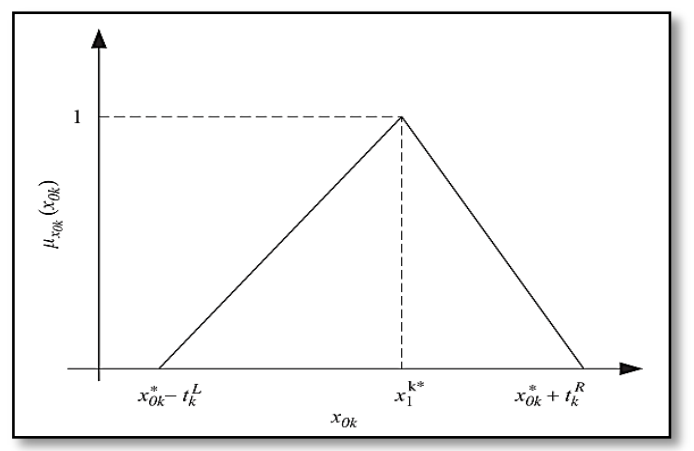

Gambar 3.2. Fungsi keanggotaan dari vektor keputusan $x_{0 k}, k=1,2, \ldots, n_{0}$. 
Dapat diperhatikan pada Gambar 3.2 bahwa $t_{k}^{l}$ dan $t_{k}^{R}, k=1,2, \ldots, n_{0}$ adalah suatu nilai toleransi negatif dan positif maksimum yang dipertimbangkan oleh ULDM berdasarkan pada kebutuhan, keinginan, dan situasi praktis dalam situasi DM, toleransi $t_{k}^{l}$ dan $t_{k}^{R}$ ini belum tentu sama. Maka toleransi ini akan memberikan para DM pada level yang lebih rendah suatu daerah feasibel yang diperluas untuk mencari solusi yang memuaskan. Kemudian dengan algoritma yang diusulkan, solusi yang memuaskan dari masalah BL-MOLP dapat dicapai (Pramanik dan Roy, 2006) dan (Sinha, 2003).

Sedemikian sehingga fungsi keanggotaan linear (Gambar 4.2) untuk masing-masing $n_{0}$ komponen dari vektor keputusan $\boldsymbol{x}^{0^{*}}=\left(x_{01}^{*}, x_{02}^{*}, \ldots, x_{0 n_{0}}^{*}\right)$ yang dikontrol oleh ULDM dapat dirumuskan sebagai berikut.

$$
\mu_{x_{0 k}}\left(x_{0 k}\right)=\left\{\begin{array}{c}
\frac{x_{0 k}-\left(x_{0 k}^{*}-t_{k}^{L}\right)}{t_{k}^{L}}, \text { jika } x_{0 k}^{*}-t_{k}^{L} \leq x_{0 k} \leq x_{0 k}^{*} \\
\frac{\left(x_{0 k}^{*}+t_{k}^{R}\right)-x_{0 k}}{t_{k}^{R}}, \text { jika } x_{0 k}^{*} \leq x_{0 k} \leq x_{0 k}^{*}+t_{k}^{R},, k=1,2, \ldots, n_{0} \\
0, \quad \text { jika lainnya }
\end{array}\right.
$$

Dapat diperhatikan bahwa DM mungkin menginginkan menggeser rentang dari $x_{0 k}$. Berdasarkan Pramanik dan Roy (2006) dan Sinha (2003) pergeseran ini dapat dicapai. Akibatnya, dalam ranah keputusan fuzzy, pencapaian dari fuzzy goal dalam artian fuzzy goal dari fungsi objektif DM pada kedua tingkat dan vektor fuzzy goal dari variabel keputusan yang dikontrol oleh ULDM ke level aspirasi dari masing-masing fungsi objektif untuk memperluas kemungkinan pencapaian solusi optimal sebenarnya diwakili oleh pencapaian kemungkinan dari masingmasing nilai keanggotaan ke tingkat tertinggi.

\subsection{Pendekatan fuzzy goal programming (FGP) untuk masalah BL-MOLP}

Dalam pendekatan Fuzzy Programming (FP), derajat tertinggi dari fungsi keanggotaan adalah 1. Jadi, seperti dalam Mohamed (1997), untuk fungsi keanggotaan yang didefinisikan dalam (4) dan (7), flexible membership goal dengan level aspirasi sebesar 1 dapat disajikan sebagai berikut. 


$$
\begin{aligned}
& \mu_{f_{i j}}\left(f_{i j}(\boldsymbol{x})\right)+d_{i j}^{-}-d_{i j}^{+}=1, i=0,1, \ldots, p, j=1,2, \ldots, m_{i} \\
& \mu_{x_{P k}}\left(x_{0 k}\right)+d_{0 k}^{-}-d_{0 k}^{+}=1, k=1,2, \ldots, n_{0}
\end{aligned}
$$

atau ekuivalen dengan

$$
\begin{aligned}
& \frac{u_{i j}-f_{i j}(x)}{u_{i j}-g_{i j}}+d_{i j}^{-}-d_{i j}^{+}=1, i=0,1, \ldots, p, j=1,2, \ldots, m_{i} \\
& \frac{x_{0 k}-\left(x_{0 k}^{*}-t_{k}^{L}\right)}{t_{k}^{L}}+d_{0 k}^{L-}-d_{0 k}^{L+}=1, k=1,2, \ldots, n_{0} \\
& \quad \frac{\left(x_{0 k}^{*}+t_{k}^{R}\right)-x_{0 k}}{t_{k}^{R}}+d_{0 k}^{R-}-d_{0 k}^{R+}=1, k=1,2, \ldots, n_{0}
\end{aligned}
$$

dengan $d_{0 k}^{-}=\left(d_{0 k}^{L-}, d_{0 k}^{R-}\right), d_{0 k}^{+}=\left(d_{0 k}^{L+}, d_{0 k}^{R+}\right)$, dan $d_{i j}^{-}, d_{0 k}^{L-}, d_{0 k}^{R-}, d_{0 k}^{+}, d_{0 k}^{L+}, d_{0 k}^{R+} \geq 0$ dengan $d_{i j}^{-} \times d_{i j}^{+}=0, \quad d_{0 k}^{L-} \times d_{0 k}^{L+}=0$, dan $d_{0 k}^{R-} \times d_{0 k}^{R+}=0, i=0,1, \ldots, p, j=$ $1,2, \ldots, m_{i}$, dan $k=1,2, \ldots, n_{0}$ deviasi bawah dan atas dari setiap level aspirasinya.

Dalam Goal Programming (GP) konvensional, variabel deviasi bawah dan/atau atas termasuk dalam fungsi pencapaian untuk meminimalkan mereka yang bergantung pada jenis fungsi objektif yang akan dioptimalkan. Dalam pendekatan ini, hanya variabel deviasi atas untuk fuzzy goal dari fungsi objektif $d_{i j}^{+}, i=0,1, \ldots, p, j=1,2, \ldots, m_{i}$ dan variabel deviasi atas dan bawah untuk fuzzy goal dari variabel keputusan, $d_{0 k}^{L-}, d_{0 k}^{L+}, d_{0 k}^{R-}$, dan $d_{0 k}^{R+}, k=1,2, \ldots, n_{0}$, yang diperlukan untuk meminimumkan keinginan untuk mencapai level aspirasi fuzzy goal. Sementara itu, dapat diperhatikan bahwa setiap deviasi bawah dari fuzzy goal $d_{i j}^{-}, i=0,1, \ldots, p, j=1,2, \ldots, m_{i}$ menunjukkan pencapaian penuh nilai keanggotaan (Baky, 2009).

Dengan mengkaji Mohamed (1997), pendekatan FGP untuk masalah MOP dikembangkan oleh Baky (2009) untuk merumuskan FGP untuk Bi-level MOLP. Oleh karena itu, mengingat masalah pencapaian tujuan dari goal pada tingkat prioritas yang sama, model masalah fuzzy bilevel multiobjective linear goal programming yang ekuivalen dari permasalahan yang dibahas dapat dirumuskan sebagai berikut. 


$$
\begin{aligned}
\min Z= & \sum_{j=1}^{m_{0}} w_{0 j}^{+} d_{0 j}^{+}+\sum_{j=1}^{m_{1}} w_{1 j}^{+} d_{1 j}^{+}+\cdots+\sum_{j=1}^{m_{p}} w_{p j}^{+} d_{p j}^{+}+ \\
& \sum_{k=1}^{n_{0}}\left[w_{k}^{L}\left(d_{k}^{L+}+d_{k}^{L-}\right)+w_{k}^{R}\left(d_{k}^{R+}+d_{k}^{R-}\right)\right]
\end{aligned}
$$

dengan kendala

$$
\begin{aligned}
& \frac{u_{i j}-f_{i j}((\boldsymbol{x}))}{u_{i j}-g_{i j}}+d_{i j}^{-}-d_{i j}^{+}=1, i=0,1, \ldots, p, j=1,2, \ldots, m_{i} \\
& \frac{x_{0 k}-\left(x_{0 k}^{*}-t_{k}^{L}\right)}{t_{k}^{L}}+d_{0 k}^{L-}-d_{0 k}^{L+}=1, k=1,2, \ldots, n_{0} \\
& \frac{\left(x_{0 k}^{*}+t_{k}^{R}\right)-x_{0 k}}{t_{k}^{R}}+d_{0 k}^{R-}-d_{0 k}^{R+}=1, k=1,2, \ldots, n_{0} \\
& A_{1} x_{1}+A_{2} x_{2}\left(\begin{array}{l}
\leq \\
= \\
\geq
\end{array}\right) \boldsymbol{b}, \boldsymbol{x} \geq 0 \\
& \quad d_{i j}^{-}, d_{i j}^{+} \geq 0 \text { dengan } d_{i j}^{-} \times d_{i j}^{+}=0, i=0,1, \ldots, p, j=1,2, \ldots, m_{i} \\
& d_{0 k}^{L-}, d_{0 k}^{L+} \geq 0 \text { dengan } d_{0 k}^{L-} \times d_{0 k}^{L+}=0, k=1,2, \ldots, n_{0} \\
& d_{0 k}^{R-}, d_{0 k}^{R+} \geq 0 \text { dengan } d_{0 k}^{R-} \times d_{0 k}^{R+}=0, k=1,2, \ldots, n_{0}
\end{aligned}
$$

dengan $Z$ merupakan fungsi pencapaian fuzzy yang terdiri dari bobot variabel deviasi atas $d_{i j}^{+}, i=0,1, \ldots, p, j=1,2, \ldots, m_{i}$ dari fuzzy goal dan variabel deviasi bawah dan deviasi atas, $d_{0 k}^{L-}, d_{0 k}^{L+}, d_{0 k}^{R-}$, dan $d_{0 k}^{R+}, k=1,2, \ldots, n_{0}$ untuk fuzzy goal dari semua variabel ULDM, dengan bobot numerik $w_{i j}^{+}, w_{k}^{R}$, dan $w_{k}^{L}$ yang menyatakan kepentingan relatif dari pencapaian level aspirasi dari masing-masing fuzzy goal terhadap batasan yang ditetapkan dalam situasi keputusan.

Untuk menilai kepentingan relatif dari fuzzy goal dengan benar, skema pembobotan yang disarankan oleh Mohamed (1997), dapat digunakan untuk menetapkan nilai-nilai $w_{i j}^{+}, w_{k}^{R}$, dan $w_{k}^{L}$.

$$
\begin{gathered}
w_{i j}^{+}=\frac{1}{u_{i j}-g_{i j}}, i=1,2, \ldots, p, j=1,2, \ldots, m_{i} \\
w_{k}^{L}=\frac{1}{t_{k}^{L}} \operatorname{dan} w_{k}^{R}=\frac{1}{t_{k}^{R}}, k=1,2, \ldots, n_{0}
\end{gathered}
$$

\section{Algoritma FGP untuk menyelesaikan masalah BL-MOLP}

Model FGP (13) memberikan keputusan yang paling memuaskan untuk semua DM pada dua tingkat dengan mencapai level aspirasi dari membership goal sejauh mungkin di lingkungan keputusan. Dari pembahasan di atas, algoritma 
pendekatan FGP untuk memecahkan masalah DBL-MOLP adalah sebagai berikut (Baky, 2009).

\section{Algoritma Pendekatan FGP}

Langkah 1. Menghitung nilai individu minimum dan nilai individu maksimum dari semua fungsi objektif dalam dua tingkat terhadap batasan kendala yang diberikan.

Langkah 2. Menetapkan level aspirasi $g_{i j}$ dan batas toleransi atas $u_{i j}$ dengan $i=0,1, \ldots, p, j=1,2, \ldots, m_{i}$ untuk semua fungsi objektif dalam dua tingkat.

Langkah 3. Mengevaluasi bobot $w_{i j}^{+}=\frac{1}{u_{i j}-g_{i j}}, i=1,2, \ldots, p, j=1,2, \ldots, m_{i}$

Langkah 4. Menentukan fungsi keanggotaan $\mu_{f_{0 j}}\left(f_{0 j}(\boldsymbol{x})\right), j=1,2, \ldots, m_{0}$ untuk fungsi objektif tingkat atas.

Langkah 5. Merumuskan Model (5) untuk masalah MOLP dari DMo.

Langkah 6. Memecahkan Model (5) untuk mendapatkan $\boldsymbol{x}^{0^{*}}=\left(\boldsymbol{x}_{0}^{*}, \boldsymbol{x}_{1}^{*}, \ldots, \boldsymbol{x}_{p}^{*}\right)$, $\boldsymbol{x}_{0}^{*}=\left(x_{01}^{*}, x_{02}^{*}, \ldots, x_{0 n_{0}}^{*}\right)$.

Langkah 7. Menetapkan nilai-nilai toleransi maksimum negatif dan positif pada vektor keputusan $\boldsymbol{x}_{0}^{*}=\left(x_{01}^{*}, x_{02}^{*}, \ldots, x_{0 n_{0}}^{*}\right)$, yaitu $t_{k}^{L}$ dan $t_{k}^{R}, k=$ $1,2, \ldots, n_{0}$.

Langkah 8. Mengevaluasi $w_{k}^{L}=\frac{1}{t_{k}^{L}}$ dan $w_{k}^{R}=\frac{1}{t_{k}^{R}}, k=1,2, \ldots, n_{0}$.

Langkah 9. Menentukan fungsi keanggotaan $\mu_{x_{0 k}}\left(x_{0 k}\right), k=1,2, \ldots, n_{0}$ untuk vektor keputusan tingkat atas.

Langkah 10. Menentukan fungsi keanggotaan $\mu_{f_{i j}}\left(f_{i j}(\boldsymbol{x})\right), i=1,2, \ldots, p, j=$ $1,2, \ldots, m_{i}$ untuk fungsi objektif dari semua DM tingkat bawah.

Langkah 11. Merumuskan Model (13) untuk masalah DBL-MOLP.

Langkah 12. Menyelesaikan Model (13) untuk mendapatkan solusi kandidat untuk masalah DBL-MOLP. 
Langkah 13. Jika DM telah puas dengan solusi kandidat dalam langkah 12, lanjutkan ke Langkah 14, lainnya lanjutkan ke Langkah 15.

Langkah 14. Berhenti dengan solusi yang memuaskan untuk masalah DBL-MOLP. Langkah 15. Memodifikasi level aspirasi $g_{i j}$, dan batas toleransi atas $u_{i j} i=$ $0,1, \ldots, p, j=1,2, \ldots, m_{i}$, untuk semua fungsi objektif dalam kedua level, kembali ke Langkah 3.

\section{Contoh}

Diberikan masalah BL-MOLP sebagai berikut:

(upper level)

$\left[D M_{0}\right]: \min _{x_{0}}\left(f_{01}=2 x_{0}-x_{1}+2 x_{2}, f_{02}=2 x_{0}+x_{1}-3 x_{2}, f_{03}=3 x_{0}-x_{1}+x_{2}\right)$ dengan $x_{1}$ dan $x_{2}$ menyelesaikan

(lower level)

$\left[D M_{1}\right]: \min _{x_{1}}\left(f_{11}=x_{0}-x_{1}-4 x_{2}, f_{12}=-x_{0}+3 x_{1}-4 x_{2}\right)$

$\left[D M_{2}\right]: \min _{x_{2}}\left(f_{21}=7 x_{0}+3 x_{1}-4 x_{2}, f_{22}=x_{0}+x_{2}\right)$

dengan kendala

$$
\begin{aligned}
& x_{0}+x_{1}+x_{2} \leq 3 \\
& x_{0}+x_{1}+x_{2} \geq 1 \\
& x_{0}+x_{1}-x_{2} \leq 1 \\
& x_{2} \leq 0.5 \\
& x_{0}, x_{1}, x_{2} \geq 0
\end{aligned}
$$

Batasan kendala $\mathrm{G}$

Penyelesaian: Pertama, menghitung solusi optimal individu minimum dan maksimum dari semua fungsi objektif pada level atas dan bawah terhadap batasan kendala $G$ yang diberikan secara terpisah. Selanjutnya, nilai individu minimum $\left(\min _{G} f_{i j}\right)$ dapat diambil sebagai level aspirasi $g_{i j}$ dan nilai individu maksimum $\left(\max _{G} f_{i j}\right)$ dapat diambil sebagai batas toleransi atas $u_{i j}$, dengan $j=1,2,3$ ketika $i=0$ dan $j=1,2$ ketika $i=1,2$. Kemudian tentukan pula nilai bobot $w_{i j}^{+}=$ $\frac{1}{u_{i j}-g_{i j}}$. 
Tabel 4.1. Nilai $g_{i j}, u_{i j}$, dan $w_{i j}^{+}$untuk setiap fungsi objektif atas dan bawah

\begin{tabular}{|cc|c|c|c|c|c|c|c|}
\hline & & $f_{01}$ & $f_{02}$ & $f_{03}$ & $f_{11}$ & $f_{12}$ & $f_{21}$ & $f_{22}$ \\
\hline $\min _{G} f_{i j}$ & $\left(g_{i j}\right)$ & -1 & -1 & -1 & -2.5 & -3.5 & -0.5 & 0 \\
\hline $\max _{G} f_{i j}\left(u_{i j}\right)$ & 4 & 2 & 5 & 1 & 3 & 8.5 & 2 \\
\hline \multicolumn{2}{|c|}{$w_{i j}^{+}$} & 0.2 & 0.333 & 0.167 & 0.286 & 0.154 & 0.111 & 0.5 \\
\hline
\end{tabular}

Sedemikian sehingga diperoleh model FGP (5) untuk masalah MOLP dari $D M_{0}$ :

$\min Z_{u}=0.2 d_{01}^{+}+0.333 d_{02}^{+}+0.167 d_{03}^{+}$

Dengan kendala

$$
\begin{aligned}
& -0.4 x_{0}+0.2 x_{1}-0.4 x_{2}+d_{01}^{-}-d_{01}^{+}=0.2 \\
& -0.607 x_{0}-0.333 x_{1}+x_{2}+d_{02}^{-}-d_{02}^{+}=0.333 \\
& -0.5 x_{0}+0.167 x_{1}-0.167 x_{2}+d_{03}^{-}-d_{03}^{+}=0.167 \\
& x_{0}+x_{1}+x_{2} \leq 3 \\
& x_{0}+x_{1}+x_{2} \geq 1 \\
& x_{0}+x_{1}-x_{2} \leq 1 \\
& x_{2} \leq 0.5 \\
& x_{0}, x_{1}, x_{2}, d_{i j}^{-}, d_{i j}^{+} \geq 0, \text { untuk } i=0, j=1,2,3
\end{aligned}
$$

Model permasalahan (17) merupakan masalah program linear biasa, diperoleh solusi optimal $x^{0^{*}}=\left(x_{0}^{0^{*}}, x_{1}^{0^{*}}, x_{2}^{0^{*}}\right)=(0,0.5,0.5)$ dan nilai penyimpangan (variabel deviasi) $d_{01}^{-}=0.298, d_{01}^{+}=0, d_{02}^{-}=0, d_{02}^{+}=0, d_{03}^{-}=0.166, d_{03}^{+}=0$. Dari solusi optimal ini, ULDM dapat memutuskan $x_{0}^{0^{*}}=0$. Jika ULDM ditetapkan toleransi positif dan negatif $t_{k}^{L}=t_{k}^{R}=1$, maka diperoleh $w_{k}^{L}=w_{k}^{R}=$ 1, sehingga diperoleh rumusan model FGP untuk masalah BL-MOLP berdasarkan model (13) :

$$
\begin{gathered}
\min Z_{u}=0.2 d_{01}^{+}+0.333 d_{02}^{+}+0.167 d_{03}^{+}+0.286 d_{11}^{+}+0.154 d_{12}^{+}+0.111 d_{21}^{+} \\
+ \\
0.5 d_{22}^{+}+d_{01}^{L-}+d_{01}^{L+}+d_{01}^{R-}+d_{01}^{R+}
\end{gathered}
$$


dengan kendala

$$
\begin{aligned}
& -0.4 x_{0}+0.2 x_{1}-0.4 x_{2}+d_{01}^{-}-d_{01}^{+}=0.2 \\
& -0.607 x_{0}-0.333 x_{1}+x_{2}+d_{02}^{-}-d_{02}^{+}=0.333 \\
& -0.5 x_{0}+0.167 x_{1}-0.167 x_{2}+d_{03}^{-}-d_{03}^{+}=0.167 \\
& 0.154 x_{0}-0.462 x_{1}+0.62 x_{2}+d_{12}^{-}-d_{12}^{+}=0.54 \\
& 0.78 x_{0}-0.33 x_{1}+0.44 x_{2}+d_{21}^{-}-d_{21}^{+}=0.06 \\
& -0.5 x_{0}-0.5 x_{2}+d_{22}^{-}-d_{22}^{+}=0 \\
& x_{0}+d_{01}^{L-}-d_{01}^{L+}=0 \\
& -x_{0}+d_{01}^{R-}-d_{01}^{R+}=0 \\
& x_{0}+x_{1}+x_{2} \leq 3 \\
& x_{0}+x_{1}+x_{2} \geq 1 \\
& x_{0}+x_{1}-x_{2} \leq 1 \\
& x_{2} \leq 0.5 \\
& x_{0}, x_{1}, x_{2}, d_{i j}^{-}, d_{i j}^{+} \geq 0, \text { untuk } i=0, j=1,2,3 \text { dan } i=1,2, j=1,2 \\
& d_{01}^{L-}, d_{01}^{L+}, d_{01}^{R-}, d_{01}^{R+} \geq 0
\end{aligned}
$$

Model permasalahan (18) merupakan masalah program linear biasa dengan solusi optimal $\boldsymbol{x}^{*}=\left(x_{0}^{*}, x_{1}^{*}, x_{2}^{*}\right)=(0,1,0)$ dan nilai fungsi objektif

$$
f_{01}=-1, f_{02}=1, f_{03}=-1, f_{11}=-1, f_{12}=3, f_{21}=3, f_{22}=0 \text {. }
$$

Selanjutnya dengan menggunakan (4) dapat dicari nilai fungsi keanggotaan dari masing-masing fungsi objektif yaitu

$$
\begin{gathered}
\mu_{f_{01}}(-1)=1, \mu_{f_{02}}(1)=0.333, \mu_{f_{03}}(-1)=1, \mu_{f_{11}}(-1)=0.571, \\
\mu_{f_{12}}(3)=0, \mu_{f_{21}}(3)=0.611, \mu_{f_{22}}(0)=1,
\end{gathered}
$$

serta diperoleh nilai penyimpangan (variabel deviasi)

$$
\begin{gathered}
d_{01}^{-}=0, d_{01}^{+}=0, d_{02}^{-}=0.6, d_{02}^{+}=0, d_{03}^{-}=0, d_{03}^{+}=0, d_{11}^{-}=0.428, d_{11}^{+}=0, \\
d_{12}^{-}=1.002, d_{12}^{+}=0, d_{21}^{-}=0.39, d_{21}^{+}=0, d_{22}^{-}=0, d_{22}^{+}=0, d_{01}^{L-}=0, \\
d_{01}^{L+}=0, d_{01}^{R-}=0, d_{01}^{R+}=0 .
\end{gathered}
$$

Berdasarkan nilai fungsi keanggotaan dari masing-masing fungsi objektif di atas, jika diasumsikan bahwa DM telah merasa puas akan hasil optimumnya, maka program nya berhenti (STOP). Namun demikian, apabila DM belum merasa puas akan hasil yang diperoleh maka DM dapat kembali memodifikasi level aspirasi 
$g_{i j}$, dan batas toleransi atas $u_{i j}$, untuk $j=1,2,3$ ketika $i=0$ dan $j=1,2$ ketika $i=1,2$, untuk semua fungsi objektif dalam kedua level, kembali ke Langkah 3.

\section{Kesimpulan}

Dalam penelitian ini masalah pemrograman bilevel multiobjektif, secara efektif dapat diselesaikan dengan menggunakan pendekatan Fuzzy Goal Programming (FGP). Salah satu keuntungan dari pendekatan ini adalah bahwa kemungkinan menolak solusi lagi dan lagi oleh pengambil keputusan tingkat pertama dan reevaluasi masalah yang berulang kali melalui pendefinisian ulang fungsi keanggotaan yang ditimbulkan, dalam keperluan untuk mencapai keputusan yang memuaskan tidak muncul. Selain itu, model FGP juga memiliki peran untuk meminimalkan kekesalan tingkat kepuasan dari kedua kelompok pengambil keputusan sehingga dapat diperoleh solusi yang paling memuaskan bagi kedua pengambil keputusan. Hal ini dapat dicapai dengan meminimumkan penyimpangan-penyimpangan dari masing-masing definisi fungsi keanggotaan tujuan.

\section{Daftar Pustaka}

H. S. Shih, Y.J. Lai, E.S. Lee, Fuzzy approach for multi-level programming problems, Computers and Operations Research 23(1) (1996), 73-91.

Ibrahim A. Baky, Fuzzy goal programming algorithm for solving decentralized bi-level multi-objective programming problems, Fuzzy Sets and Systems, 160 (2009), 2701-2713.

Y. J. Lai, Hierarchical optimization: a satisfactory solution, Fuzzy Sets and Systems, 77 (1996), 321-335.

S. Pramanik, T. Kumar Roy, Fuzzy goal programming approach to multi-level programming problems, European Journal of Operational Research, 176 (2006), 1151-1166.

S. Sinha, Fuzzy programming approach to multi-level programming problems, Fuzzy Sets and Systems, 136 (2003), 189-202. 
R. H. Mohamed, The relationship between goal programming and fuzzy programming, Fuzzy Sets and Systems, 89 (1997), 215-222. 
